opened hard, and by hook or crook with her delicate thumb-nail, she managed one day in forcing the back open to wind the watch, to break the hinge, and so I cant use it until your people put it in order, for I wont let these bunglers out here look at it."

Kit Carson, it seems, was guiding Major Carleton's expedition against the Apaches.

"I told him," says the Major, "that if he would find the Indians for me on that day I would give him a beaver hat. He told me in the morning soon after we had started from camp, that he knew by the 'sign' we should come up with them. Said he, 'I will shew them to you at 2 o'clock this afternoon.'

At 5 min. to 2. P. M. we discovered the camp on the summit of Fischer's Peak -- whipped the Indians - and Kit won his hat."

Major Carleton's subsequent career in the Civil War was a distinguished one. In 1862, he commanded the "California Column," and he was later raised to the rank of Brigadier-General. He was ordered to relieve General Canby in the command of the Department of New Mexico, which he retained for several years, taking part in several engagements. Afterward, he was brevetted MajorGeneral for conduct during the War. Since the last of his letters to Bigelow Brothers and Kennard, we have only the bare facts of his military record. The box of old papers of that firm has not been completely unpacked, and it is to be hoped that it will prove to contain some of the later impressions of their sprightly correspondent of the 'fifties.

\title{
Records of a Universal Science
}

Although Dr. Einstein has shaken our faith in the very existence of an absolute standard of measure or weight, the expression of length, area, volume and weight by comparison with standards which to our senses appear to be stable will continue to be a necessity of human society, even of the very existence of mankind. As John Quincy Adams stated it:

"Weights and measures may be ranked among the necessaries of life to every individual. ... They enter the economical arrangements and daily concerns of every family. They are necessary to every occupation of human industry; to the distribution and security of every species of property; every transaction of trade and commerce; to the labors of the husbandman; to the ingenuity of the artificer; to the studies of the philosopher; to the researches of 
the antiquarian; to the navigation of the mariner and the marches of the soldier, to all the exchanges of peace and all the operations of war."

A bundle of manuscript extracts from ancient and modern sources dealing with weights and measures, recently received from Europe, led to our discovery that a remarkable collection of the literature of this universal science had been accumulated during the past twenty-nine years by Samuel S. Dale, of Brookline, Massachusetts. In a special room in Mr. Dale's house are eleven or twelve hundred volumes and between six and seven hundred pamphlets, dating from 1520 to the present time. His purpose in gathering this library is to "bring together so far as possible a copy of every book, pamphlet, government document and other printed or written matter dealing with the origin, history, development and science of weights and measures that has ever been issued in any language at any time."

He has already advanced far toward this object, for nineteen different languages are represented. The English, French, German, Italian, Swedish and Latin sections contain some very rare and interesting books. Mr. Dale receives as they appear all the reports on weights and measures issued by the Russian Soviet Government. There are smaller groups in Danish, Norwegian, Spanish and Japanese, and a few books each are in Chinese, Siamese, Czechoslovakian, Dutch, Hungarian, Polish, Portuguese and Hindustani. A collection of indexed scrapbooks is included, the clippings in which, if laid end to end, would reach approximately one and a quarter miles.

This remarkable mass of information was begun as a by-product of Mr. Dale's interest in the question whether or not the United States ought to change to the metric system of weights and measures. The first few books he picked up were intended as a working collection, without a thought of beginning a library. Like Topsy, it "just grew," until one day Mr. Dale found himself in possession of a library of considerable size, and the habit of collecting books. After that he acquired anything he saw which had any connection with the development of weights and measures, with the result that the small room in which he keeps his books on ninety-eight feet of shelving is filled with every sort and description of volume, report and pamphlet relating to his subject, altogether forming probably as comprehensive a collection of the science of weights and measures as is to be found anywhere. His views on the metric 


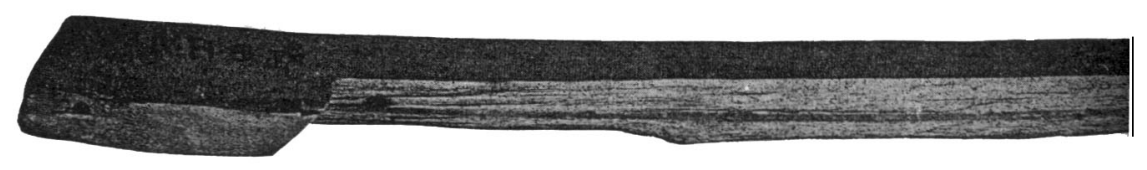

Two viEwS of to

THE insCription Was WritTEN ON THE hazelwood

controversy were not allowed in any degree to influence his selection of items. The collection has been made with absolute impartiality.

Some of the older books, one, for example, written in Toledo in I 599, by a Spanish Jesuit, "Johannis Marianae Hispani Socié Jesu, De Ponderibus et Mensuris," are beautifully bound in old vellum. The oldest book in the collection, was printed by Froben, one of the most famous of the early Swiss printers and a friend of Erasmus, and deals with "sestertii, talents, moneys, weights and measures."

The earliest of the German books, dated 1619, having much to say about the gauging of wine casks, is one of a series of mathematical works, principally arithmetical, running from 1584 to 1926 . These illustrate the development of the use of weights and measures as taught in arithmetics in various countries at different periods.

The French section begins with the ordinances of Louis XIV "concerning the jurisdiction of the Mayors and Aldermen of the City of Paris," many of which relate to weights and measures, and continues up to the most recent French publications, including all the documents issued by the International Bureau of Weights and Measures at Sèvres. There is a fine set of the three volume "Système Métrique" of Méchain and Delambre, the two scientists who, at the time of the French Revolution, measured the arc of the meridian from Dunkirk to Barcelona as a basis for the metric system. Perils beset these workers in the cause of science during that time of social upheaval. In the course of their work, the scientists flashed signals to each other from neighboring hilltops and 

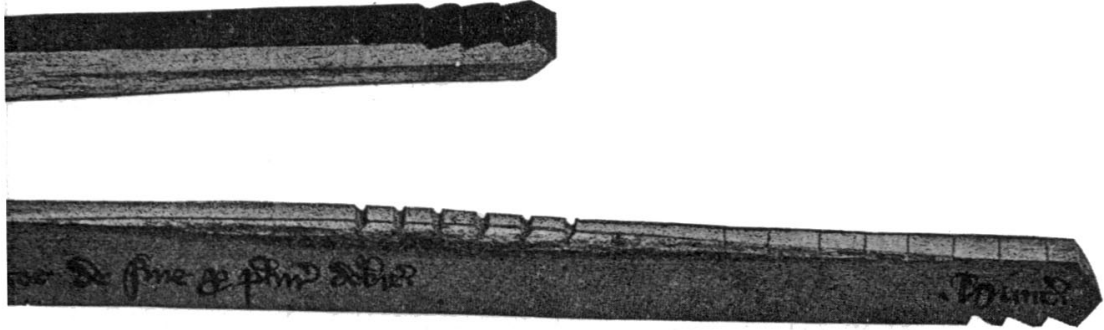

SH TALLY STICK.

QUILL PEN, DIPPED IN THE JUICE OF THE GALL NUT

were repeatedly arrested as royalists hatching some plot against the Revolution. Méchain's task was to measure the Southern section of the arc. Having finished his observations of stars, base lines and angles during the winter of $1792-93$, Méchain, realizing that Paris was no safer for scientists than for aristocrats, decided to protract his stay in the South as long as possible. Here he found leisure to watch the comet of 1793 , the various occultations of the stars, and the eclipse of the moon on February 25, I793. He expected to finish this work in a few weeks, but before it was completed, he was invited to inspect a hydraulic machine which a friend had invented and installed near Barcelona. The horses which were to supply the power were employed elsewhere, and the inventor and his assistant started to operate the machine by hand. Méchain, standing near on rising ground to watch the flow of water into the tank, suddenly heard cries of distress. Turning, he saw that his friend and the helper had started the machine but could not control it. Rushing to their assistance, he was struck by the arm of the contrivance, which was moving rapidly in reverse. His collar bone was broken, and he remained unconscious for three days and was forced to be idle for several months.

Compelled by the Spanish authorities to remain in Spain, he decided to repeat the astronomical observations he had made before his accident to determine the latitude of Fort Mont-Jouy near Barcelona. The record of these had already been sent to Paris. He found a discrepancy of three seconds of a degree between the measurement sent to Paris and that resulting from his second observation. Frightened by the discovery, weakened by his in- 
juries and tormented by fears as to the fate of his wife and children who were at Paris in the midst of the bloody turmoil of the Revolution, he decided to conceal the error, which was not discovered until after his death, when the length of the meter had been based on the erroneous record.

Another French work of especial interest is the "Mémoires sur le Système Métrique des Anciens Egyptiens," of E. Jomard, one of the corps of scientists attached to Napoleon's Egyptian expedition. While Napoleon urged his troops to battle with the reminder that from the Pyramids they were being watched by forty centuries, Jomard and his co-workers were patiently and laboriously searching for the exact size of the stade, cubit, foot, palm, condyle and doight, the units by which the Egyptians, five thousand years before Napoleon's time, had made the measurements which were inseparable from their daily activities.

Three methods were used by the scientișts. The first was to search for the cubit-rules in the ruins of the ancient civilization. The second was to measure the distances from place to place in Egypt, and the dimensions of the monuments, for which measurements had been given in old Egyptian units by ancient writers. The third was to measure the buildings and monuments with a view to discovering whether or not some of the common units of ancient Egypt were aliquot parts of their dimensions.

The first method included the cubits marked on the walls of the nilometers. These were walled cisterns connected with the waters of the Nile. Their purpose was to show the height of the Nile flood, on which the harvest so largely depended.

Herodotus, Diodorus of Sicily, Strabo, Artemidore of Ephesus, Erasthenes, Hipparchus, Pliny and the itinerary of Antoine were the sources for the second method. In order to compare with his own measurements the distances they gave in ancient units, Jomard measured the distances between many points in Egypt, among them those from Heliopolis to Thebes, Mount Casius to the Arabian Gulf, the Pyramids to the Nile and Memphis, Memphis to the Delta, Cyrene to Philae, and Pharos to Canopus.

The third method involved the dimensions of such structures as the Great Pyramid, the monument and statue of Osymandyas, the temple of Isis at Karnak, the tombs of the Kings, the obelisks at Thebes, Karnak and Luxor, the columns of Diocletian at Alexandria, the colossi of:Memphis, Karnak, Luxor and Memnon, and the monoliths at Mehallet el-Kebyr and Philae. All these were studied 


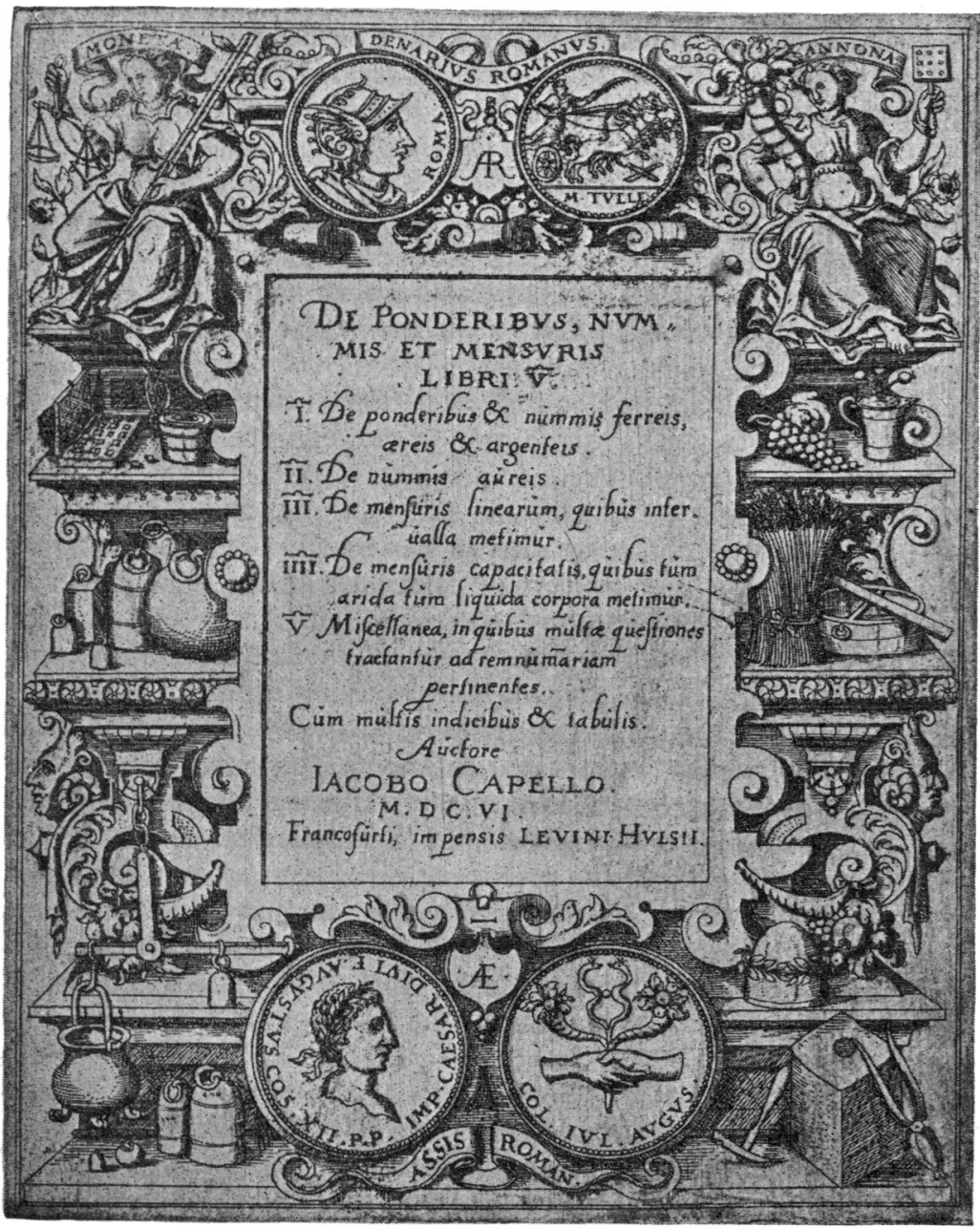

An ornamented title page from one of Mr. Dale's rare old volumes. This one, Printed in I606 at Frankeurt, TREATS OF WEIGHTS, COINS AND MEASURES 
to find multiples of the ancient units of Egypt. The results of this laborious research are embodied in Jomard's book, as a monument to his own industry and Napoleon's breadth of vision.

Locked in a tin box under the shelves of the Dale library in order to protect it from the fading effects of sunlight is an old English tally stick, which came into Mr. Dale's possession as an incident of his study of weights and measures in Europe. And thereby hangs a tale of absorbing interest. The stick is a relic of the old system of keeping accounts at the British Exchequer, used before writing on paper had become a common accomplishment. Mr. Dale describes the system in a paper read before the Lawrence Textile School in 1908:

"When a person deposited money with that institution the clerk cut notches in a stick, which was about eight inches long and three-eighths inch square. There was a deep notch for each pound sterling, a small notch for each shilling, and a scratch or slit for each penny of the amount deposited. The depositor's name and the date were then written on two sides of the stick.

"The tally clerk next sawed the stick half in two at a point a short distance from the end and then split it lengthwise into two pieces, one longer than the other and having a butt at one end. The two pieces had each the same number of notches and each bore the date of the deposit and the name of the depositor. The smaller piece was given to the depositor as a certificate of the deposit; the larger piece was retained in the Exchequer as a record of the transaction. If a piece of paper is torn in two we have two pieces that match when brought together, but no other piece can ever be torn to match either of the first two. And so with the tally sticks. No other stick could ever be split to match either the one held by the depositor or the one in the Exchequer. Counterfeiting was impossible.

"When the depositor wanted his money, he presented the stick at the Exchequer, the corresponding piece was found, the two were fitted together, and the amount indicated by the notches was paid by the Exchequer. This system was in force for a thousand years or more previous to 1828 , when the last payment on a tally stick of which there is any record, was made."

During the centuries that tally-stick records were in use the lives of Jew and Christian, rich and poor, hung in a precarious balance. Depositors fell in the wars, or were victims of religious persecution or the inconstancy of royal favor. Unclaimed deposits 
accumulated, represented by a growing pile of tally sticks, in the basement of the House of Lords, which in the course of time became a nuisance. Finally, in 1834, the Government ordered them destroyed. On the morning of October 16, two or three men began to feed them into the furnace beneath the House of Lords.

"A little pile of notched sticks bearing strange looking inscriptions in abbreviated Latin and old English script. The evidence of thrift for a thousand years. Tokens of all the motives that prompt men and women to save, love and hate, greed and sacrifice, hope and fear, frugality and fraud, the proceeds of honest toil and of crime, held for ages that the missing pieces carried away by successive generations might be redeemed, their presence a mute evidence of the blasted hopes of depositors for a thousand years."

All day the work of burning the sticks continued. In the afternoon the woman caretaker in the room above sent a boy to the basement several times to warn the busy firemen that the wall of the room was getting very hot. On each occasion, the chief fireman, a man who had served time in an Australian penal colony, sent word back to the woman that he knew his business and the woman should mind hers.

A few minutes before seven that evening, as the men were crowding the last of the sticks in to the roaring furnace in order to finish the job, the overheated furnace flue started a blaze which immediately got beyond control and in a few hours reduced both Houses of Parliament to a mass of smouldering ruins, destroying all the British Government's basic standards of weights and measures. New standards were made from a number of accurate copies of the lost ones in the possession of scientific societies and the Ordnance Survey, so that the fire had no effect on the stability of English standards.

Several of the tally sticks were saved, and one of them is now appropriately a part of the Dale library. The notches testify to

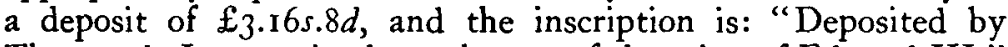
Thomas de Lovetot in the 2oth year of the reign of Edward III," (I347), five hundred and eighty-two years ago. This deposit in 1347 , if kept at $6 \%$ interest compounded annually, would now, in 1929, amount to twenty thousand one hundred and seventy-two times $\$ 320,000,000,000$, the total wealth of the United States.

Such a review as this hardly scratches the surface of the information in this library concerning weighing and measuring processes, essential to every human activity, and whose importance in the 
conduct of business is expressed by this motto with which one William Benedict prefaced his book on the subject in 1698 :

$$
\begin{aligned}
& \text { "Wer sich in Müntz und Wechseln ubt, } \\
& \text { Vergleichung der Gewichte liebt } \\
& \text { Und Maass und Elle richtig giebt"; }
\end{aligned}
$$

which may be freely rendered:

$$
\begin{aligned}
& \text { "Who by finance and commerce liveth } \\
& \text { All measurements correctly giveth; } \\
& \text { And loveth ever such a one } \\
& \text { Of weights the just comparison." }
\end{aligned}
$$

\section{Inn Atemoriam}

IN THE last month the Society has lost from its membership Mr. Felix Fuld, who has long been a prominent figure in the world of business, and in those of art and philanthropy as well. He died on January 20, at his home in South Orange, New Jersey. Mr. Fuld was born in Frankfurt-on-Main, Germany, in 1869 , and came to America when he was fourteen. His father, Ludwig Fuld, was a partner in a New York banking firm. The boy was privately educated in New York.

Three months after the founding of the Newark department store of L. Bamberger and Company, in 1892 , the younger Fuld joined Louis Bamberger as an equal partner. At the time of his death Mr. Fuld was vice president, treasurer and general manager. He was also vice-president of the WOR radio station owned by the store, and was connected with various publishing and banking activities.

In philanthropic circles he was no less active than in business, although he was extremely reticent about his good works. He was head of the Newark Federation of Jewish Charities, and of the State Federation of Young Men's and Young Women's Hebrew Associations, and a member of the board of directors of the Beth Israel Hospital in Newark. When the Newark Community Chest campaign fell \$150,000 short of its goal recently, Mr. Fuld and one other man made good the deficit. There was no end to his interest in any worthy cause. He did much in the way of providing social centers for young men and women. Both he and his wife, formerly Miss Carrie Bamberger, contributed largely in aid of Jewish farm 